\title{
ARMENIAN GENOCIDE SURVIVORS: THE STRUNGA ORPHANAGE IN ROMANIA ${ }^{1}$
}

\author{
Lidia Prisac
}

Motto: A child without parents is like a house without a roof

Varujan Vosganian

This article examines the history of the 200 children rescued from massacres that took place during the Armenian Genocide, who found shelter in Greater Romania (1918-1940), in the Strunga orphanage, which was open for three years, from 1923 to 1926. The Strunga orphanage history approach reflects the dimensions of humanitarian assistance in the Kingdom of Romania on the issue of Armenian refugees, particularly on the fate of children after the genocide. The reconstruction of this orphanage history is based on historical sources, such the Album of Orphans (1923), archive documents and articles from the contemporary press published by the Armenian minority in interwar Romania. In general, the humanitarian dimensions of Armenian community support in Romania offered the orphans the possibility of rehabilitation after the genocide and adaptation to the new social environment that Romania represented.

Key-words: orphans, humanitarian assistance, rehabilitation, Armenian Genocide, Armenian community from Romania, Kingdom of Romania.

\section{Introduction}

The Strunga orphanage was set up in the county of Roman in the Kingdom of Romania, for orphans of Armenian origin saved from genocide. This article draws attention to a subject practically unknown to the public but resonating with the sinister events succeeding one another over more than a century within the Ottoman Empire, where more than one and a half million Armenians were massacred.

The development of the study of the Armenian exodus after genocide and the Sovietization of Armenia represents an important step in reconstructing the picture of Armenian refugees in Romania. ${ }^{2}$ The approach is part of the "more difficult stories" genre as it aims at studying one of the most vulnerable segments, namely, the life experience of children rescued from massacre. ${ }^{3}$

1 The article was received on 03.05.2020 and accepted for publication on 20.06.2020.

Strunga is a commune in the north-east of Romania, Iași County. It is situated $55 \mathrm{~km}$ from Iași city.

2 Lidia Prisac, "Exodul armenilor după genocid şi sovietizare în România regală (1915/1918-1924)," in The 1st Annual Kurultai of the Endangered Cultural Heritage - AKECH 2018 (Constanța: Anticus Press, 2018), 85-99; Lidia Prisac, Ion Valer Xenofontov, "Genocidul, refugiații armeni și România Mare (1918-1940)," in Akademos. Revistă de știință, inovare, cultură și artă 46, no. 3 (2017): 103-112; Lidia Prisac, "Problema emigrării armenilor peste Nistru în România interbelică în documentele Arhivei Naţionale a Republicii Moldova," in Istorie, Cultură şi Cercetare, Vol. II (Deva: Editura Cetatea de Scaun, 2017), 172-188.

3 Florence M. Soghoian, Portrait of a Survivor (Brand: Christopher Publishing House, 1997); L'enfant et le génocide. Témoignages sur l'enfance pendant la Shoah (Paris: Editions Robert Laffont, 2007); Suzanne Kaplan, 
Initially, the study was intended to be based exclusively on articles in the contemporary press published by the Armenian minority in interwar Romania. But, after a research internship at the Armenian Genocide Museum-Institute in Yerevan, where I had the chance to study the Album of Orphans from Strunga (1923), ${ }^{4}$ I decided to use this historical source as a guide in reconstructing the history of the orphanage. The research would not have been complete had I not used archived documents kept in the collections of the Armenian Archdiocese of Romania, which helped reveal the fate of orphaned children following the closure of that charity establishment. I also appealed for stories from orphans who had been housed in Strunga. ${ }^{5}$

Being part of the historiography concerning the consequences of the Armenian Genocide, my research started from two impulses - the first, the continuing interest and topicality of the subject of the Armenian Genocide, the second determined by the need to outline, at a historiographical discourse level, the subject of the charity work in Romania carried out for the care of Armenian orphans. An overview of the research about the Strunga orphanage story reveals that there are almost no studies to have approached the subject in a detailed way, ${ }^{6}$ the main ones being more like types of review. ${ }^{7}$ Yet, among the works published so far, my attention was drawn to a $\mathrm{PhD}$ thesis defended at "Babeş-Bolyai" University of Cluj-Napoca, the author of which, in a chapter on refugee aid organizations, also covers the issue of the establishment and closure of the Armenian orphanage in Strunga, which was open for three years, from 1923 to $1926 .^{8}$

What I would like to do in this study is to understand and delve into the narrative of humanitarian assistance in the Kingdom of Romania concerning Armenian refugees, particularly the fate of the children moved there after the genocide. Although the Armenian community as a whole participated in the establishment of the orphanage and supported the children in Strunga, my attention has mainly focused on the contribution made by the Armenians in Bessarabia that officially formed a community of 1,509 people. ${ }^{9}$

Children in Genocide. Extreme Traumatization and Effect Regulation (London: International Psychoanalytical Association, 2008).

4 Centenar Genocid/Albumul Orfanilor de la Strunga, at https://www.araratonline.com/albumul-orfanilor-de-la-strunga/, accessed 25.09.2019.

5 "Hairabed Bostangian: În Turcia era interzis să-ţi faci semnul crucii," in Mărturii. Genocidul armenilor, realizat de Mihai Stepan Cazazian şi Eduard Antonian (Bucureşti: Editura Ararat, 1998), 106-108; Strunga. Documentary made by Cadri Abdula, producer, Mihai Stepan Cazazian, at https://www.youtube.com/watch?time_continue $=12 \& \mathrm{v}=\_3 \mathrm{v} 29 \mathrm{CctW} 1 \mathrm{Y} \&$ feature $=$ emb_title $\&$ fbclid $=$ IwAR0SJ6nZzy66CpqNTPdZ0xUsx m8OOdU81wu37OjB93yuhmNrmJeeAIhFCcc\%20, accessed 30.05.2020.

6 In 1930 international public opinion knew practically nothing about the situation of Armenian refugees in the Kingdom of Romania, let alone orphans. La situation des enfents des refugiés russes et armeniens en 1930. Rapport du Sous-Comité pour l'étude de la Condition des enfants des réfugiés du Comité Consultative des organisations privées auprès du Haut-Commissaire pour des Réfugiés de la Société des Nations (Genève: Union Internationale des secours aux enfants, 1930), 42.

7 Sergiu Selian, Schiță istorică a comunității armene din România (București: Editura Ararat, 1999), 111; Andreea Tănase, Sfârşit de istorie la Strunga (27.04.2010), at http://www.araratonline.com/sfar\%C8\%99it-de-istorie-la-strunga/, accessed 25.05.2019; Andreea Tănase, Armenians in Romania. The Stories of the People Closet to Us (Bucharest: Master Print Super Offset, 2015), 345-347.

8 Claudia Dărăban, Impactul genocidului asupra evoluției comunității armene din România interbelică (Teză de doctorat în Relaţii Internaţionale şi Studii de Securitate, Cluj-Napoca, 2018), 156-161.

9 Recensământul general al populației României din 29 decembrie 1930, Vol. II (București, 1938), XXIV. 


\section{Contextualizing the Emergence of Charities for Orphans}

The Armenian Genocide generated clear solidarity in international humanitarian assistance. Aid for the approximately $500,000^{10}$ Armenian survivors - out of a population of about 2 million ${ }^{11}$ - was carried out worldwide by organizations and individuals who were or weren't of Armenian origin. ${ }^{12}$ Armenian refugee relief organizations were established immediately after the massacres, between 1916-1923, especially in Eastern Armenia, ${ }^{13}$ on the territories bordering the Ottoman Empire, and later around the world. ${ }^{14}$ When the International Society of the Middle East assembly took place in Geneva on 3 September 1926, 20 Armenian organizations from the USA, Scandinavia, Belgium, Switzerland, France, etc. also participated. ${ }^{15}$

The League of Nations set up a Commission of Inquiry to study the situation of deported women and children. The American missionary and nurse Emma Darling Cushman, one of its three members, prepared estimates of the numbers of Armenian orphans. In the context of the organized exterminations that took place in 1921, the number of Armenian orphans was found to be 12,480 in the unoccupied areas and 11,339 in the occupied territo-

10 Around 200,000 Armenians would have escaped forced deportations from Constantinople and Smyrna. Another 300,000 would have found refuge in the Caucasus and other territories of the Tsarist Empire. Hagop Asatryan, "Impactul Primului Război Mondial asupra formării diasporei armene," in Primul Război Mondial şi influenţa sa asupra formării Diasporei Armene, Materialele conferinţei internaţionale, 26-28 septembrie 2014 (Bucureşti: Zamca, 2015), 113.

11 In 1914 the number of Armenians in Western Armenia was estimated at 1,198,000 and in Cilicia at 205,050 (not considering the Armenians of the other regions of the Ottoman Empire). Later, by 1921, 75,000 had taken refuge from there in Syria (from Cilicia), in Palestine - 3,500; in Mesopotamia - 6,000; in Yerevan - 200,000; in the North Caucasus - 60,000; in the Black Sea region - 60,000; in Persia or America - 20,000, the total number making 464,000 refugees. Subsequently, due to the massacres of 1922, another 60,000 Armenians took refuge in Greece; in Bulgaria - 10,000; in Algeria, Tunisia and Egypt - 1,500; in France - 1,350; in Italy - 850. Hagob Turabyan (ed.), L'Arménie et la Question Arménienne avant, pendant et depuis la guerre (Paris: Imp. Turabian, 1922), 9, 70-71. According to the modern research by the Armenian scholars, the number of Armenians living in the Ottoman Empire before WWI was 2,488,100, of whom 1, 675, 800 were living in the Western Armenia and

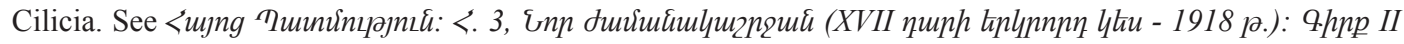

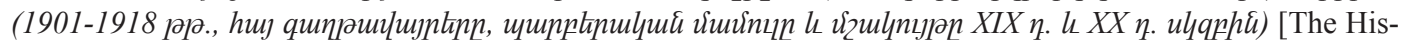
tory of Armenia, vol. III. Modern Era (Second half of the XVII century - 1918), book 2 (1901-1918, Armenian settlements, periodical press and culture in the XIX century and the beginning of the XX century)], eds. Ashot Melkonyan et al. (Yerevan: NAS RA, Institute of History, 2015), 64.

12 Dzovinar Kévonian, Réfugiés et diplomatie humanitaire. Les acteurs européens et la scène proche-orientale pendant l'entre-deux-guerres (Paris: Sorbonne, 2014), 541.

13 Положение беженцев в Александропольском районе [The situation of Refugees in Alexandropol Region], (Baku: Tipografiya Pervogo Tipograficheskogo Tovarishchestva, 1915); Prist S. Aslanyan, Среди беженцев (Личные впечатления). Перепечатка из “Астраханского вестника" [Among the Refugees (Personal Impressions). Reprint from “Astrakhan Vestnik”] (Astrakhan: Tipografiya A.A. Shtyl'ko, 1915) Grigor Chalkhush'yan, Красная книга [The Red Book], (Rostov on Don: Tipografiya Ashkhatank, 1919).

14 See the newspaper collection Армяне и Война [Armenians and War] (Odessa), 1916, 1917, 1918, or Армянский Вестник [The Armenian Bulletin] (Moscow), 1916, 1917, 1918; Armenian Red Cross and Refugee Fund. First Annual Report (London: np, 1915); Second Annual Report (London: np, 1916); Third Annual Report (London: np, 1917); Fourth Annual Report (London: np, 1918); Fifth Annual Report (London: np, 1919); Sixth Annual Report (London: np., 1920). See also: Eduard Narcis Antonian, "Armenii din Imperiul Otoman la începutul secolului XX," in Mărturii. Genocidul armenilor, 80-84.

15 “Chestiunea orfanilor armeni la Geneva," in Ararat (Bucharest), October 1926, no. 28, 5. 
ries. The approximate or unofficial total number of orphans living in the unoccupied areas was estimated at 60,750 and in the occupied territories 12,600 .

In order to save them from Islamisation and provide them with places of safety as a large part of them were in Turkish locations, the premise of the Commission for the Protection of Women and Children of the Middle East became the "House of the League of Nations," thus allowing the transfer of children to other places, institutions or charities, or to their relatives or families who had managed to survive. From Constantinople, now Istanbul, the children were sent abroad. ${ }^{16}$

\section{Armenian Orphans in Romania}

After completing the necessary formalities and a medical examination 200 orphaned children arrived by ship in Romania on 12 April $1923 .{ }^{17}$ Transporting them to the Romanian coast, on a stormy sea, took one day, the children being accompanied by Khachadour N. Vosdanigian, secretary of the Union of Armenians in Romania (UAR) ${ }^{18}$ in charge of bringing the orphans to the country. ${ }^{19}$

According to contemporary testimonies, the children who disembarked in Constanța "had been gathered up from the sides of roads" or "taken from under carts transporting dead people...," "some had been taken from the breasts of their dying mothers..., others had been entrusted to authorities or charity institutions by the parents themselves..." They "had lived in orphanages run by scattered groups from Adana to Beirut or used as labor in the weaving mills of Aleppo and Damascus. Each child was wearing a cardboard placard around his neck with his Armenian name on it. ${ }^{20}$

Hairabed Bostanjian stated that when they landed in Constanţa, "A mass of people, both men and women, Armenians and Romanians, were there" to meet them, "waving handkerchiefs, some with tears in their eyes, others making the sign of the cross." 21

If we examine the data from the Album with reference to the orphaned children (which, in some places, are incomplete), despite the fact that the information concerning eight out of 150 boys has been removed, that the profile photos are missing of 18 children (10 girls and 8 boys) and only 174 of the 200 children were photographed, we can still conclude that the orphans were born between 1906 and 1918. The majority went through the ordeal of genocide; most were born in 1911 (35 in number), followed by those born in 1913 (32); 1909 (25); 1910 (23); 1912 (20); 1914 (18); 1908 (16) etc. The youngest was 5 years old, and the oldest was 17.

Among the orphans were those who, at the beginning of the massacres, were only a

16 Kévonian, Réfugiés et diplomatie humanitaire, 145-146, 151-152.

17 In some sources there were 198 children, in others 400 children. Varujan Vosganian, Cartea șoaptelor (Ediția a II-a, Iaşi: Polirom, 2012), 399-400.

18 Established in early 1919, the organization had the mission of taking on and assisting Armenian refugees. Archive of the Armenian Archdiocese of Romania (AAAR), D. 471, 12; D. 161, 1-99.

19 Edvard Jeamgocian, U.A.R. 100 /Khaciadur N.Vosdanighian [1864(?)-feb. 1942], primul secretar al Uniunii Armenilor din România: 1919-1922, at http://www.araratonline.com/u-a-r-100-khaciadur-n-vosdanighian-1864feb-1942-primul-secretar-al-uniunii-armenilor-din-romania-1919-1922/, accessed 05.01.2020.

20 Vosganian, Cartea şoaptelor, 401.

21 AAAR, D. 260, 161-168; Bostangian, In Turcia era, 106. 
few days old; others were from one to a few months old, others being between one and nine years old. ${ }^{22}$ Most of the children, 34, came from Ordu, followed by Stanoz (17 children), Chankere (13), Ankara (11), Kapan Maden (11 children), Erzerum (8), Amasia (8), Constantinople (7), Kesaria (6), Adabazar (6), Brusa (5), Kastemuni (4), Sebastia (3), Eskishehir (3) and one-two orphans from other localities in the Ottoman Empire.

The data entered shows that there were children who bore the same surname, which leads me to believe that they were brothers, sisters or relatives. For example, the three Karaoghlanian boys: Norair, 9, Haikazun, 10, and Haik, 13, were all born in Changra; or the Kahvegian girls: 10-year-old Vergin, 11-year-old Araxi and 12-year-old Azaduhi, who were born in Stanoci.

Examining the photos of the children, who seem, in some pictures, to be scared and disorientated, it can be seen that they wore modest clothing of a uniform style. Many boys displayed the tip of a white handkerchief protruding from the pockets of their shirts. The girls had short haircuts (probably for hygienic reasons) and almost all of them had bows in their hair and wore a beaded pendant with a medallion or cross around their necks.

Regarding the children's physical and mental condition when they arrived in Strunga, we can conclude from the reports in the magazine Ararat that they were facing certain health problems, having been witnesses to the horrors of genocide. If some did seem healthy, others were affected by skin diseases (possibly as a result of neuro-psychiatric disorders or malnutrition). ${ }^{23}$ During the massacres, some children became infected with tuberculosis, which was a fatal disease in the early 20th century. The orphan Azaduhi Somangian, who had nobody - her parents having died during the deportations, a sister being abducted by the Kurds and an older brother killed in front of her - brought the disease from Asia Minor, where she came from. After a life of wandering from village to village, the girl reached Brusa, from where she was sent to Constantinople and, later, to Strunga in Romania, together with the other orphans. Living with Anton Ştefănescu's family in Bacău for two years, where, together with four other orphans, she enjoyed that adoptive family's care. She died at the age of 17 of galloping tuberculosis in the Bârnova sanatorium, mourned by orphanage friends and the Ştefănescu family. ${ }^{24}$

\section{Foundation of the Orphanage in Moldova ${ }^{25}$}

As early as the summer of 1921, the National Council of the Patriarchate of Constantinople established, in Bucharest, a branch of the Fundraising Committee for Orphans, one of whose representatives was Khachadour N. Vosdanigian. Later, in November 1921, the

22 In 1915, Hayrabed Bostangian, reached the age of $6 \ldots$ and in 1915-1920 he had lost all connection with the rest of the family... Borrowing a Turkish name, he was admitted to a Turkish orphanage, with about 4,000 Turkish, Greek and Armenian children. Bostangian, In Turcia era, 106.

23 “Locale," Ararat, June 1925, no. 12, 7; December 1926, no. 30, 8; July 1927, no. 37, 8.

24 "Locale," Ararat, July 1925, no. 13, 7.

25 Moldova was one of the 10 provinces of the Great Romania (Muntenia, Oltenia, Dobrogea, Transilvania, Banat, Crișana, Maramureș, Bucovina and Bessarabia), located in the East of the country, between the Carpathian Mountains and the Prut River. Is not to be confused with actual Moldova (Republic), successor of RSSM/ Bessarabia. 
Committee was renamed as the Orphanage Committee, which was at the basis of the Armenian orphanage establishment in Strunga. ${ }^{26}$

The Armenian community in Romania worked very hard to open the orphanage. Many people, led by Armenag Manisalian as well as Khachadour N. Vosdanigian made numerous tours around the country and to Constantinople, activities which took more than a year.

With the approval of King Ferdinand I, the orphanage received the 200 children, with the authorization of the Romanian Government and a collective passport endorsed by the Romanian Ministry of the Interior dated 18 November 1922, on 1 April 1923. ${ }^{27}$

Hairabed Bostangian remembers that before arriving at the orphanage, the orphans, "... while waiting to leave for Strunga were hosted by Armenian families from Constanţa and Bucharest." 28

According to the Album, the children entered the orphanage on 1 May 1923, arriving by carts at their destination. Although there is nothing in Strunga to recall the existence of the former orphanage, it is certain that it was founded, almost a century ago, by the generosity of the Manolescu-Strunga family, the humanitarian aid being provided by the UAR in the person of its president, Armenag Manisalian ${ }^{29}$ (who had also become the chairman of the central committee of the orphanage), as well as with the support of the Armenian community of Romania.

Located in an area with sulfurous mineral waters, the orphanage was housed in a building meant for spa baths. Founded in 1880 at the initiative of the landowner and Dr. Nicolae Manolescu-Strunga (1850-1910), the baths had gone into decline during WWI.

The orphanage building had over 30 rooms and an infirmary, laundry, bathroom, kitchen (where Sofia Agop, a widow with two children, cooked), ${ }^{30}$ a living room, cloakroom, workshops, etc. plus housing for educators, caregivers, seamstresses and service people. The landscape around the orphanage seemed to be soothing, as anyone could spend their time "in the midst of the fir trees." ${ }^{11}$ Manush Mardirosian (born on 15 August 1915 in a locality in Persia), who arrived in Strunga with her father who was a teacher, remembers that the orphans were housed in some beautiful buildings, behind which was a hill with a small church on it, the walls of which had carved Armenian inscriptions. A forest and a field full of flowers that were like a carpet of violets was in front of the buildings. ${ }^{32}$ The orphanage also had large orchards with fruit trees and gardens which were cultivated by the orphans themselves to provide the vegetables needed for their daily food. According to Hairabed Bostangian's testimony, the orphanage also had a sports field and children's' playgrounds. ${ }^{33}$ Even though the area offered a feeling of safety, the children were not exempt from bad

26 Jeamgocian, U.A.R. 100.

27 AAAR, D. 177, 33; D. 260, 62.

28 Bostangian, În Turcia, 107.

29 "Statutele Orfelinatului Armean din România," Ararat, 1 August 1924, no. 2, 2.

30 AAAR, D. 260, 162.

31 "În jurul Orfelinatului," Ararat, April 1925 no. 10, 3; "Serbarea Orfelinatului," Ararat, September 1925, no. 15,5 .

32 See min. 27 in Strunga Documentary.

33 "Informațiuni," Ararat, July 1, 1924, no. 1, 7; "Transferarea Orfelinatului," Ararat, April 1926, no. 22, 5; Bostangian, Î́n Turcia, 107. 
weather. The orphanage was affected by an unusually heavy hail storm, which caused damage estimated at 15,000 lei ${ }^{34}$, in June 1924. Later, in the spring of 1926, Strunga was covered with a vast amount of snow. ${ }^{35}$

\section{Orphanage Administration and Management}

The Council of the Armenian Diocese of Romania appointed a central committee for a period of five years for the administration of the institution, composed of a chairman, vice-chairman, secretary and three advisers, their positions being honorary. The central committee was later completed with three new members: K. Eksergian, Hazarian and A. Acikgheozian. The vice-chairman, K. Eksergian, had the task of managing things at Strunga in Armenag Manisalian's absence. ${ }^{36}$

The orphanage central committee was in Bucharest, on Calea Victoriei Street. It was responsible for administering funds, appointing and replacing the principal and the entire staff of the orphanage, setting salaries, vetting and approving members of the orphanage management and organizing regional committees (initially 18, later, starting in 1924, 22). If comparison is made of the number of regional committees by province, it can be seen that the most numerous were in Vechiul Regat (Old Kingdom), followed by those in Bessarabia, Cetatea Albă (Akkerman), Chișinău, Bălți and Hâncești. The regional committees were responsible for covering orphanage expenses with the minimum amounts set by the general assembly, made up of all the orphanage's great and small benefactors. ${ }^{37}$

\section{Education and Other Activities at the Orphanage}

A four-grade primary school based on a three-year curriculum was opened in Strunga for the orphans' education, including an elementary vocational school. In order to train the orphans for a profession, the orphanage also set up two workshops for boys (one for shoemaking and another for wood turning) and a workshop for girls (for making oriental carpets). Thanks to the Nefian brothers, merchants in Bucharest, the carpet workshop was equipped with 12 weaving looms. ${ }^{38}$

Education at the orphanage was compulsory and was conducted in accordance with the curriculum of Armenian schools in Romania as approved by the Ministry of Public Instruction, the school courses being conducted in Romanian and Armenian. Although children were on vacation in summer, Romanian language lessons continued uninterrupted so that by the end of August, the children would be able to pass their examinations. In actual fact, the orphans made significant progress in the second year, especially in learning the language of their host country. ${ }^{39}$ Recalling past events, Hairabed Bostangian said that some

34 The Romanian leu (plural lei) is the currency of Romania.

35 “Știri de la Orfelinat," Ararat, 1 August 1924, no. 2, 5; “Locale," Ararat, April 1926, no. 22, 8.

36 “'Orfelinatul," Ararat, April 1925 no. 10, 7; “Locale,” Ararat, July 1925, no. 13, 8.

37 "Statutele Orfelinatului Armean din România," Ararat, 1 August 1924, no. 2, 2; "Orfelinatul," Ararat, July 1926 , no. 25,5 .

38 "Transferarea Orfelinatului," in Ararat, April 1926, no. 22, 5; "Adunare Generală anuală a Orfelinatului Armean din România," in Ararat, 1 July 1924, no. 1, 6; "Locale," Ararat, January 1925, no. 7, 8.

39 "Știri de la Orfelinat," Ararat, August 1, 1924, no. 2, 5; "Adunare Generală anuală a Orfelinatului Armean 
of the children could neither read nor write. As for the teachers: "We were surrounded by staff filled with unimaginable love and we felt very good, as if forgetting the 'fire' we had gone through..."40

Among the orphanage mentors and teachers were the principal, deputy principal and teachers of the institution. For three years, until June 1926, "showing diligence, honor, and invaluable features as an organizer and educator," Sarkis Srintz was the principal: "an eminent teacher and diplomatist of the Nancy Normal School". He helped in reorganizing some incomplete committees and visited Bessarabia, Moldova and Bukovina to raise money for the orphans. Following the closure of the orphanage, Sarkis Srintz was appointed as a teacher at the Armenian school in Bucharest. On his initiative a circle of former orphanage students from Strunga was formed - "Casa noastră" (Our House), where single young people gathered, eating together and "... after leaving the workshops, keeping busy with useful reading." $" 41$

Eliza Srintz, the principal's daughter, a graduate of the English College in Constantinople, also worked at Strunga by the autumn of $1925 .{ }^{42}$ Nshan Maganian, Armenian language teacher, who settled in Romania in 1922, taught history and geography at the orphanage. ${ }^{43}$

Thanks to their teachers, the children learned both school subjects and to recite verses in Armenian and Romanian and to sing and dance. Various celebrations or commemorations in which children were involved tell us of the skills learnt by the orphans. Under the leadership of the principal and the teachers, April 24 was commemorated with both a religious service and a memorial one, held in the orphanage's chapel. ${ }^{44}$ On May 10 (Romanian royal day), the principal would give a patriotic speech, and a religious service would be held in the orphanage's chapel. On May 13, the orphans would attend the solemn commemoration of the Unknown Hero, which would take place in the local cemetery. Another celebration was related to the creation of the Armenian alphabet on St. Mesrob's Day. ${ }^{45}$

The orphanage's anniversary was another important event that was held every year and a program was prepared with the utmost care. A detailed description of the second anniversary celebration may be read in Ararat magazine. It began on Sunday, September 7, 1924, and lasted for two days in superb weather. The arrival of the guests was facilitated by a special car service, which brought them from Tg. Frumos station to Strunga. Guests arrived from Bucharest, Constanța, Cernăuți, Galați, Brăila, Iași, Suceava, Botoșani, Roman, Bacău, Tg. Ocna, Brădulești and Tg. Frumos. ${ }^{46}$

din România," Ararat, 1 July 1924, no. 1, 6.

40 Bostangian, În Turcia, 107.

41 "De la Orfelinat," Ararat, January 1925, no. 7, 8; "Locale," Ararat, November 1925, no. 17, 8; October 1926, no. 28, 7; October 1928 no. 52, 8; March 1930, no. 4 (60), 8.

42 The principal had three daughters: Annig, Eliza and Armine. The latter was soon lost, and the former left for Greece in 1924 to marry the Armenian professor Nerses Balian, who later, both, returned to Romania. AAAR, D. 260, 125; "De la Orfelinat," Ararat, August 1926, no. 26, 7; "Locale," Ararat, October 1926, no. 28, 7; Vosganian, Cartea şoaptelor, 400.

43 "Nâșan Maganian (1891-1978)," at http://personalitati.araratonline.com/maganian-nasan-1891-1978/, accessed 01.06.2020; see min. 21 in Strunga Documentary.

44 "De la Orfelinat," Ararat, May 1925, No.11, 7.

45 “Locale," Ararat, June 1926, no. 24, 8; “Informațiuni,” Ararat, 1 July 1924, no. 1, 7; "Locale," Ararat, June 1926, no. 24, 8; "Știri de la Orfelinat," Ararat, 1 August 1924, no. 2, 5.

46 "Știri de la Orfelinat," Ararat, 1 August 1924, no. 2, 5. 
Although physically absent, representatives of Bessarabia's regional committees also joined the anniversary through several written messages. For example, the chairman of the committee from Hânceşti, Tosunianţs, sent a greeting: “....regretting not being able to take part in the celebration, we send you our joyful and warm greetings and congratulations... Long live His Majesty the King and the dynasty. Long live great Romania." From Chișinău, the following telegram came from the priest Rev. Zadigian: "I congratulate you and I hope you continue the work begun with the same wonderful ardor ..."47

The celebratory religious service began at 10 o'clock, led by the priest Rev. Leon Papazian, ${ }^{48}$ in the presence of Bishop Husig Zohrabian, accompanied by the choir of orphans conducted by Stepan Sagheldian. After the service, the guests, led by orphans, visited the orphanage gardens. At 12 o'clock a table, set on the orphanage terrace and adorned with wildflowers awaited the guests. The series of toasts was begun by Armenag Manisalian, who praised the principal and the entire staff for their work for the good of the children. At the end, he wished good health for the king and queen, the glory and greatness of Romania, the hospitable country where a handful of children had found shelter.

Later, at $2 \mathrm{pm}$, the school celebration began in the large orphanage hall, adorned with garlands of flowers, greenery and flags, which was opened with the royal anthem sung by the school choir. Dozens of children ascended the improvised tribune, reciting in Romanian and Armenian. Armenian national dances aroused admiration among the spectators.

The final part of the program, which included gymnastics and various games, held on the field in front of the main pavilion, took place later in the evening, the boys being led by masters Maganian and Mardiros, and the girls by Miss Eliza Srintz. ${ }^{49}$

The New Year celebration was marked by children through various songs. In general, children were educated in the spirit of the adoptive country's identity, being taught to cherish and love Romania's royal family. Both during and after the celebrations, the orphans were visited by different people, either to contribute to their material support, a subject I will return to below, or to encourage them through communication with them. ${ }^{50}$ Regarding the visits to the orphanage, Hairabed Bostangian remembers that between 1923 and 1924 conditions were unforgettable. Many Armenians ...visited them very often, always providing the children with food, clothing and other necessary things. ${ }^{51}$

Another custom established at the orphanage was the organization of excursions. To visit the Olympic Games on 19 July 1925, a group of 24 orphans met Father Măgărdici Bodurian for tea. ${ }^{52}$ It became a real artistic celebration lasting for three hours.

In addition to the stated activities, the orphanage also focused on the development of physical culture and the sports movement. The boys played football and participated in various matches. Hairabed Bostangian fondly remembers these activities: "One day... I

47 "Serbarea aniversară a Orfelinatului," Ararat, 1 October 1924, no. 4, 5-6.

48 Priest from the town of Roman, awarded with numerous decorations, including the "French Medal of Honor," at http://personalitati.araratonline.com/papazian-leon-1872-1928/, accessed 01.06.2019.

49 "Serbarea aniversară a Orfelinatului," Ararat, 1 October 1924, no. 4, 5.

50 “De la Orfelinat," Ararat, January 1925, no. 7, 8; “Locale," Ararat, May 1925, no.11, 8.

51 Bostangian, In Turcia, 107.

52 Armenian vicar-priest of the Catholic rite (1881-1959), scholar and preacher of Armenian culture, at http:// personalitati.araratonline.com/bodurian-magardici-1881-1959/, accessed 07.11.2019. 
was playing football, having sandals on that were tied with string ... Armenag Manisalian, seeing us, got very upset and ordered football boots and special T-shirts for all the boys... In another case, the orphanage was visited by an Armenian from the USA, who endowed it with baseball equipment..."53

Two football teams were set up at the orphanage: "Ararat 1" and "Ararat 2." In the summer of 1924, the "Ararat 2" team had a match against one from Tg. Frumos. At the beginning, the orphanage team was hesitant against the opposing one, but in the second half, it won the match with a score of 2 to $0 .{ }^{54}$ Practicing sports, excursions, walks and visits was a way for children to shape their personalities.

\section{Reduction of the Number of Orphans in Strunga}

During the three years of its existence, the number of children in the orphanage steadily decreased. The Album highlights the fact that a few months after its establishment, between July and November 1923, 14 children (9 boys and 5 girls) left it. In 1924, from May to December, 40 children left (34 boys and 6 girls), and from February to October 1925, another seven children left ( 4 boys and 3 girls).

The names of the children in Strunga had been published in many countries with Armenian populations in Europe. That way some children found their relatives, while others were adopted by Armenian families from France, Bulgaria, Greece, etc. Some of them, through happy circumstances, were reunited with their mothers, fathers, uncles and aunts settled in different parts of the world, such as the towns in Romania (Bucharest, Constanța, Roman, Botoșani), Bulgaria, Greece, France and the USA. In the summer of 1924, two of the children were called to Paris by an elder brother. Both embarked on the ship Robert Bella at the port of Brăila, to leave for Marseilles, from where they were to continue their journey to Paris. ${ }^{55}$

Ararat magazine reported in early 1926 that several children from the orphanage went to their close relatives who made a living in different countries - 12 left for Constantinople being called there by relatives. According to the records, the number of orphans decreased, "especially in the second year" from 200 at the beginning to $125 .{ }^{56}$

During the first general assembly that took place on 25 May 1924, a year after its opening, it was decided not to accept any more orphans except for those who were to be adopted through legal means. Subsequently, only children of adolescent age were entrusted to individuals, provided that they assumed the responsibility of taking care of them like parents and taught them a trade. Orphans could only be removed from the institution if a favorable opinion from the regional committee was obtained. ${ }^{57}$ The Armenians in Romania were informed that there were, in 1925, several boys between the ages of 15 and 17 at the

\footnotetext{
53 Bostangian, In Turcia, 107.

54 “Informațiuni," Ararat, 1 July 1924, no.1, 7; “De la Orfelinat," Ararat, May 1925, no. 11, 3.

55 "Informațiuni," Ararat, 1 July 1924, no. 1, 7.

56 “Transferarea Orfelinatului," Ararat, April 1926, no. 22, 5; "Locale,” Ararat, February 1926, no. 20, 8; “'Orfelinatul," Ararat, August 1925, no. 14, 4.

57 “Adunare Generală anuală a Orfelinatului Armean din România," Ararat, 1 July 1924, no. 1, 6; "Statutele Orfelinatului Armean din România," Ararat, 1 August 1924, no. $2,2$.
} 
orphanage who had finished primary school and had learnt a trade. They were well brought up, obedient and healthy and would be useful to those who wanted them to teach others the craft they were engaged in. ${ }^{58}$

It appears from the Album that several orphans were taken for adoption by the same person. Ardashes Bardisbanian of Bucharest had taken 5 orphans and Hagop Baclagian 4. A. Ștefănescu of Bacău adopted 3 orphans. Hairabed Bostangian reveals that he and many others like him were employed as apprentices to various Armenian merchants or craftsmen, jewelers, watchmakers, etc. "...Among my orphanage colleagues I remember Kalust Hazarian (I know he died in 1993 in Constanţa), Stepan Meldonian, Antranig Marcarian, Edvard Gearbinian... The latter was adopted by an Armenian merchant and became an aviator..."59 If we analyze the number of orphans taken by individuals by gender (even if the proportion was different, from 75 to 25 percent), we can see that boys were more often asked for than girls.

\section{Orphanage Subsidy and Supply}

The existence of the establishment was due to various donations and grants that facilitated the care of the orphans. This aspect deserves special attention when dealing with the problem. The funds the orphanage had at its disposal consisted of various taxes (around 7,000 lei per year from patrons) paid in two half-yearly installments, subscriptions (collected monthly by regional committees), voluntary donations, benefits from balls and celebrations organized by the regional committees, as well as the subsidy granted by the Romanian Ministry of Health and Social Welfare. The orphanage received an annual subsidy of 60,000 lei from the ministry, including various amounts from Banca Comercială Română (the National Bank of Romania) and many other banking and commercial institutions in Bucharest such as Banca Românească, Contin-Export, Creditul Român, Marmorosh Blank, Moara Assan, Moara Comercială, Societatea generală de Export, Societatea Intercontinentală şi Societatea Leonida (General Export Society, Intercontinental Society and Leonida Society) ${ }^{60}$ The establishment of the UAR office significantly eased the collection of monthly subscriptions. Taking 1925 alone, about 400,000 Romanian lei was paid into the orphanage's account solely from Bucharest. The orphanage's material situation could only improve with the intervention of the head of the establishment. ${ }^{61}$

In order to support and supply the orphanage, a food collection campaign or "collection of offerings in kind" was started at the initiative of the central committee. Starting in November 1924, "an ad-hoc commission composed of several people roamed Armenian merchants' shops in Calea Griviţei Street and received various quantities of sugar, tea and

58 "Locale," Ararat, June 1925, no. 12, 7.

59 Bostangian, În Turcia, 107-108.

60 "Statutele Orfelinatului Armean din România," Ararat, 1 August 1924, no. 2, 2; "Adunare generală anuală a Orfelinatului Armean din România," Ararat, 1 July 1924, no. 1, 6; "Orfelinatul," Ararat, August 1925, no. 14, 4; "Știri de la Orfelinat," Ararat, 1 August 1924, no. 2, 5.

61 "Pentru orfani," Ararat, December 1925, no. 18, 5; "Locale," Ararat, September 1925, no. 15, 8; October, November 1925, no. 16, No.17, 8; November 1926, no. 29, 8; April 1925, no. 10, 8; January 1925, no. 7, 8. 
pasta..."62 The Bucharest regional committee sent a first consignment of snacks weighing about $1,000 \mathrm{~kg}$ for the holidays at the end of 1924 , followed by two more in the first month of 1925. Various products arrived at the orphanage from the "sugar king" of Romania, Harutiun Frengian, who would donate $30 \mathrm{~kg}$ of halva at holiday time. ${ }^{63}$

Children were also offered a range of basic necessities during orphanage celebrations. For example, on the second anniversary, several benefactors - the brothers Galustian and Ohanes from Bacău, Mrs. A. Baragian, A. Bardizbanian, B. Ohanes, Messrs. Bercovici, Zakarian, Melikset, K. Măgărdician, Frimovici and others - donated flour (200 kg), sugar (30 $\mathrm{kg})$, fat $(112 \mathrm{~kg})$, cheese $(10 \mathrm{~kg})$, confectionery $(10 \mathrm{~kg})$, chocolate $(9.5 \mathrm{~kg})$, biscuits $(5 \mathrm{~kg})$, candies ( $3 \mathrm{~kg}$ ), melons (100), eggs (100), vinegar ( 8 bottles), noodles (two boxes), cream (12 boxes), chicory ( 5 boxes), socks (36 pairs), handkerchiefs (36), soap (5 kg) and toilet soap (36 tablets). ${ }^{64}$

Several people committed themselves, in 1925, to provide fabric and sewed clothes for orphans. A. Acikgeozian sent linen cloth worth 12,000 lei. Later, a group of ladies from Bucharest made 150 suits using the donated fabric. ${ }^{65}$ Armenian children themselves took part in charitable activities aimed at helping the orphans. At New Year, the students of the school in Bucharest, collecting money among them, sent their schoolmates in Strunga school supplies valued at 2,258 lei. ${ }^{66}$ Another form of orphan support was cash donations. The orphanage received various amounts, large and small, depending on the donors' means. Adina Take Ionescu, wife of the brilliant lawyer and prime minister of Romania and lady-in-waiting to Queen Maria, donated 5,000 lei; Evanghel Mataranga from Turnu Măgurele, 1,500 lei etc. ${ }^{67}$ D.A. Yughaperian, president of the Prevederea Insurance Company, donated 1,000 lei for the support of orphans when he visited the orphanage in summer 1924. Other donations of 1,$000 ; 500 ; 200 ; 100 ; 80 ; 75 ; 60$ and 50 lei came from Armenians from Gherla. The lawyer Anton Melic offered 4,000 lei during the winter holidays in $1925 .{ }^{68}$

Among the donors there were philanthropists who did not want to divulge their identities. For example, on several occasions 50,000 and 30,000 lei were sent to the orphanage by an anonymous local benefactor from Galaţi, through Aram Ghiumlushian. There were also cases of bequests made to the orphanage through wills. ${ }^{69}$

Significant sums were also raised by the Armenian regional committees for the benefit

62 “Locale," Ararat, December 1, 1924, no. 6, 8.

63 "Harutiun Frenghian," at http://personalitati.araratonline.com/frenghian-harutiun-franghian-sau-frenkian-1873-1959/, accessed 14.11.2019; "Donaţiuni," Ararat, January 1925, no. 7, 3; "De la Orfelinat," Ararat, January 1925, no. 7, 8; “Orfelinatul," Ararat, April 1925, no. 10, 7; “Locale," Ararat, April 1926, no. $22,8$. 64 “Serbarea aniversară a Orfelinatului," Ararat, 1 1924, no. 4, 6; "Locale," Ararat, August 1926, no. 26, 8.

65 “Orfelinatul," Ararat, April 1925, no.10, 7; "Locale," Ararat, May 1925, no. 11, 8; July 1925, no. 13, 8.

66 “Locale," Ararat, February 1925, no. 8, 8; "De la Orfelinat," Ararat, January 1925, no. 7, 8; "Locale," Ararat, October 1925 , no. 16,8 .

67 “Ea ...femeia din elita politică românească: Adina Take Ionescu,” at http://www.rador.ro/2015/03/01/ea-femeia-din-elita-politica-romaneasca-adina-take-ionescu/, accessed 08.11.2019; "Pentru Orfelinat," Ararat, May 1926 , no. 23, 6 .

68 “Știri de la Orfelinat," Ararat, 1 August 1924, no. 2, 5; "Donaţiuni pentru Orfelinat," Ararat, May 1925, no. 11, 3; "Locale," June 1925, no. 12, 8; "Donaţiuni," in Ararat, January 1925, No.7, 3.

69 “Locale," Ararat, October 1925, no.16, 8; December 1925, no. 18, 6; “Donaţii," Ararat, June 1925, no. 12, 4; "Locale," Ararat, January 1926, no. 19, 7. 
of the orphanage. According to the budget for 1924-1925, the revenues from the 18 committees amounted to 870,000 lei and from the committees in Bessarabia 70,000 lei. ${ }^{70}$

Although the orphans in Strunga had many well-wishers in Bessarabia, such as the chairmen of the committees in Chisinau and Balti - V. Acicov, and Iacob Marcarov, respectively, the material contribution made by Armenians from these regions was sporadic and uneven, Armenian charity work suffering largely from expropriation and the lawsuit filed in the case of Ograda Armenească (the Armenian Courtyard). ${ }^{71}$ According to Ararat magazine, an important donation came from Hâncești to Strunga from D. Tosunian, who offered 1,300 lei on its second anniversary. ${ }^{72}$ Compared to the Armenians from Hânceşti, whose numbers were significant, the community from Cetatea Albă, which was quite numerous and rich, "did not contribute any money... and did not appear in the list of donors during 1924."73

A few years later, O.I. Marcarov expressed his regret that the town of Balti could not provide an annual contribution of 7,000 lei to support the orphanage until 1926 giving, as a comparison, the small community of Suceava that had offered 27,000 lei. In order to raise a certain amount of money in support of the orphans, a committee led by Marcarov organised a charity event where the amount of 9,800 lei was collected, with another 1,000 lei being added by $\mathrm{H}$. Marcarov himself. Another 12,140 lei arrived at the orphanage from the committee about a month after that event. ${ }^{74}$

Significant donations reached the orphanage from abroad. Thus, the Armenian community in Belgrade sent 10,000 lei in March 1925. In September 1926 5,000 lei arrived on behalf of Dr. Stepanian, a former doctor in Strunga, from Tehran. ${ }^{75}$

A charity tradition was the Oriental Ball held for the benefit of the orphanage. The first of these, with the enchanting appearance of $A$ thousand and one nights took place on February 28, 1925 (a Saturday), in Liedertafel. ${ }^{76}$ Hundreds of valuable carpets and curtains, which adorned the halls, had been made available to the organizing committee free of charge by several merchants in the capital, representing a value of tens of millions of lei. There were a great number of assistants and the presence of several personalities from the elite of Bucharest was remarkable. Numerous splendid masks and costumes were to be seen and musical compositions and dances were performed by first class artists. The buffet was very grand. The ball lasted until the following morning... with the net benefit/income

70 “Locale," Ararat, May 1925, no. 11, 8; August, no. 14, 8; February, no. 8, 8; January 1926, no. 19, 7; "Bugetul orfelinatului armean din România pe anul 1924-1925," Ararat, July 1924, no. 1, 7.

71 "Prietenii orfanilor," Ararat, January 1925, no.7, 5; Lidia Prisac, "Ograda armenească din Chișinău (18131922)," in Identitățile Chișinăului. Materialele conferinţei științifice (19-20 octombrie 2017, Ediția a IV-a) (Chișinău: Arc, 2018), 161-171; Lidia Prisac, "Exproprierea Ogrăzii Armenești din Chișinău (1922-1932)," in Identitățile Chișinăului. Materialele conferinţei științifice (1-2 noiembrie 2018, Ediția a V-a) (Chișinău: Arc, 2019), 230-240.

72 "Serbarea aniversară a Orfelinatului," Ararat, 1 October 1924, no. 4, 6.

73 In 1928 there were 22 Armenian families, with 76 souls, of which some were very poor. AAAR, D. 221, 5; D. 351; “Orfelinatul," Ararat, August 1925, no. 14, 4.

74 “Corespondențe," Ararat, April 1926, no. 22, 7; “Pentru Orfelinat," Ararat, May 1926, no. 23, 6.

75 “Orfelinatul," Ararat, April 1925, no.10, 7; “Locale," Ararat, October 1926, no. 28, 7.

76 Song society, founded in Bucharest in 1852, at https://dexonline.ro/definitie/liedertafel/540913, accessed 03.06. 2019; "Ştiri diverse," Ararat, 1 December 1924, no. 6, 8; "Locale," Ararat, February 1925, no. 8, 8; November 1925, no. $17,8$. 
totaling over 200,000 lei. ${ }^{77}$ Money was collected during charity balls even after the closure of the orphanage. ${ }^{78}$

\section{General Meetings and the Closure of the Orphanage}

The first annual general assembly of patrons and donors was held at Strunga on 25 May 1924, under the chairmanship of Armenag Manisalian. The auditor's report for 1923-1924 was heard and the general budget detailing revenue and expenditure was set. The minimum amount which each regional committee was to contribute to the orphanage's expenditure was also fixed. Although a new general assembly was planned for the second year, it was never convened. ${ }^{79}$ The third was to have been held during the third year, but as a significant number of branch delegates in the country did not responded to their invitations, the meeting was postponed indefinitely. Things seemed to be generally unchanged at the orphanage, especially in terms of health... However, the idea that the orphanage would no longer be profitable because of the declining number of children began to be circulated as early as the spring of $1925 .^{80}$

According to reports in Ararat magazine, there were several voices in the community that spoke about the orphanage's unprofitability. ${ }^{81}$ In this sense, there were several solutions proposed regarding the institution. The first was to send the orphans to Armenia, which was not feasible because of the difficulties that the children would be subjected to on such a journey. Meanwhile Armenia had been sovietized. Another solution was to transfer the orphanage to Bucharest - a situation that would have been more difficult due to the rents payable which would have been greater than that paid in Strunga. ${ }^{82}$

The uncertain situation around the orphanage and the misunderstanding between the members of the establishment's central committee, made Armenag Manisalian resign from the position of central committee chairman in the summer of 1926. In the new circumstances and lack of funds, although there were still 70 orphans in the orphanage, it became necessary to create a commission elected from the executive committee to close it. Armenag Manisalian's resignation led to a series of other resignations - those of the teacher Srintz, accountant Şantarzian, deputy director Gulbenkian, as well as the principal of the orphanage, Sarkis Srintz, remaining at Strunga with only one assistant and a single teacher. ${ }^{83}$ In the autumn of 1926, another communiqué stated that at Strunga "...there were only five children

77 "Balul Orfelinatului," Ararat, March 1925, no. 9, 8.

78 "Locale," Ararat, March 1926, no. 21, 8; January 1927, no. 31, 8; March 1927, no. 33, 8; "Balul Oriental," Ararat, December 1927, no. 42, 8.

79 "Adunare Generală anuală a Orfelinatului Armean din România," Ararat, 1 June 1924, no. 1, 6; "Locale," Ararat, December 1925, no.18, 7.

80 "Locale," Ararat, September 1925, no.15, 8; February 1926, no. 20, 8; “Orfelinatul," Ararat, July 1926, no. 25,5 .

81 "În jurul Orfelinatului," Ararat, April 1925, no.10, 3-4.

82 “Transferarea Orfelinatului," Ararat, April 1926, no. 22, 5; "Locale," Ararat, May 1926, no. 23, 8.

83 "Orfelinatul," Ararat, July 1926, no. 25, 5; "Locale," Ararat, August 1926, no. 26, 8; September 1926, no. 27,8 . 
left who, like the others, were to be handed over to a master." Through these actions, it was finally decided that the orphanage should be closed. ${ }^{84}$

When informed of the resignations, the diocesan committee took into account that there were the orphans left - both boys and girls, without supervision - about 45 in all. It appointed a governing body to deal with the children's fate. The committee held several meetings and compiled a list of orphans from Bucharest. Stating that "...most of them had been directed to masters, without any commitment by the latter," the committee took steps to conclude the apprenticeship contracts provided for in labor law as soon as possible. As a result of these changes, although placed with craftsmen, many orphans actually remained on the streets. The few short reports gleaned from Ararat show the need for children to be helped, especially in cases of illness or the lack of housing. ${ }^{85}$ From archive pages referring to the former orphans from Strunga who had settled in Bucharest with some of the craftsmen there, it can be seen that UAR had intervened countless times with the Romanian Ministry of Interior in order to facilitate the issuing of identity certificates, free pass tickets, Nansen passports or extending of residence permits/tickets in Romania. ${ }^{86}$

\section{Conclusion}

The orphanage's creation and its existence in Strunga showed the place and role of the Armenian community in Romania in the process of helping refugees after the genocide. These two landmarks are important in revealing the situation the Armenian community in interwar Romania was in. The dynamic measures taken in relation to the Armenian orphans accepted by the Romanian authorities mark the efforts of the Armenians in Romania through charity actions aimed at solving the pressing problems faced by thousands of orphaned children scattered by the effects of genocide. However, the situation the orphanage was in highlights the failures that existed within the Armenian community in Romania. Caught in a broad process of adjustment to the new political-administrative framework developed after WWI, Armenians in Greater Romania found it difficult to develop a coherent line (even concerning orphans) and to stick to it in a context in which points of view in the Vechiul Regat (Romanian Old Kingdom, from 1881 till 1918) and in the rest of the provinces were clearly different. Speaking of the Armenians from Bessarabia, ${ }^{87}$ it can be stated, that they joined the centralization that was emerging from Bucharest quite late; in this sense, we distinguish, at

84 "Locale," Ararat, November 1926, no. 29, 8; April 1927, no. 34, 8; "Statutele Orfelinatului Armean din România," Ararat, 1 August 1924, no. 2, 2.

85 "Locale," Ararat, December 1926, no. 30, 8; January 1927, no. 31, 8; May 1927, no. 35, 7; June 1927, no. 36, 8; September 1928, no. 51, 8 .

$86 A A A R$, D. 177, 33; D. 260, 15, 39, 57, 62, 68, 70, 72, 90, 109, 120, 126, 133, 136-138.

87 Lidia Prisac, Ion Gumenâi, "Armenii din Basarabia în contextul Marii Uniri," in Historia est Magistra Vitae: Valori, paradigme, personalități: In honorem profesor Ion Eremia (Chişinău, Tipografia Centrală, 2019), 547561; Ion Gumenâi, Lidia Prisac, "Between Separation an Unity in the Context of the Great Union. Armenians from Bessarabia," in World War and the Birth of a New World Order: the End of an Era, ed. by Ioan Bolovan and Oana Mihaela Tămaș (Newcastle upon Tyne: Cambridge Scholars Publishing, 2020), 184-203; Lidia Prisac, "Prezențe armenești în Sfatul Țării: Petre Bajbeuc-Melicov," in Centenar Sfatul Țării: 1917-2017. Materialele conferinței științifice internaționale (Chișinău, 21 noiembrie 2017) (Chișinău: Lexon Prim, 2017), 443-458. 
the country level, a heterogeneous rather than a homogeneous Armenian community.

Some of the orphans who reached Romania were lucky, managing to find their relatives and to be reunited with their lost families. The massacres, exodus and their rescue had deeply marked the lives of the Armenian orphans who arrived in Strunga. In their eyes, the Armenian community in Romania looked as being well entrenched in a country where Christian values were the norm.

Despite existing dissensions within the Armenian community in Romania and the declining support for orphans in Strunga, it can be stated that the humanitarian aspect meant nothing more than offering the possibility of rehabilitation after the genocide and adaptation to the new social environment that Romania represented.

\section{Acknowledgment}

This work is partially the product of my research undertaken at the Armenian Genocide Museum-Institute, Yerevan, as a Raphael Lemkin Scholar in 2019. I would like to thank all my colleagues and the staff at the AGMI for their support, especially Harutyun Marutyan who offered me the content of the Orphans' Album and Shushan Khachatryan, who helped me translate the information about each orphan from Armenian.

\section{Photos of Children of the Strunga Orphanage}
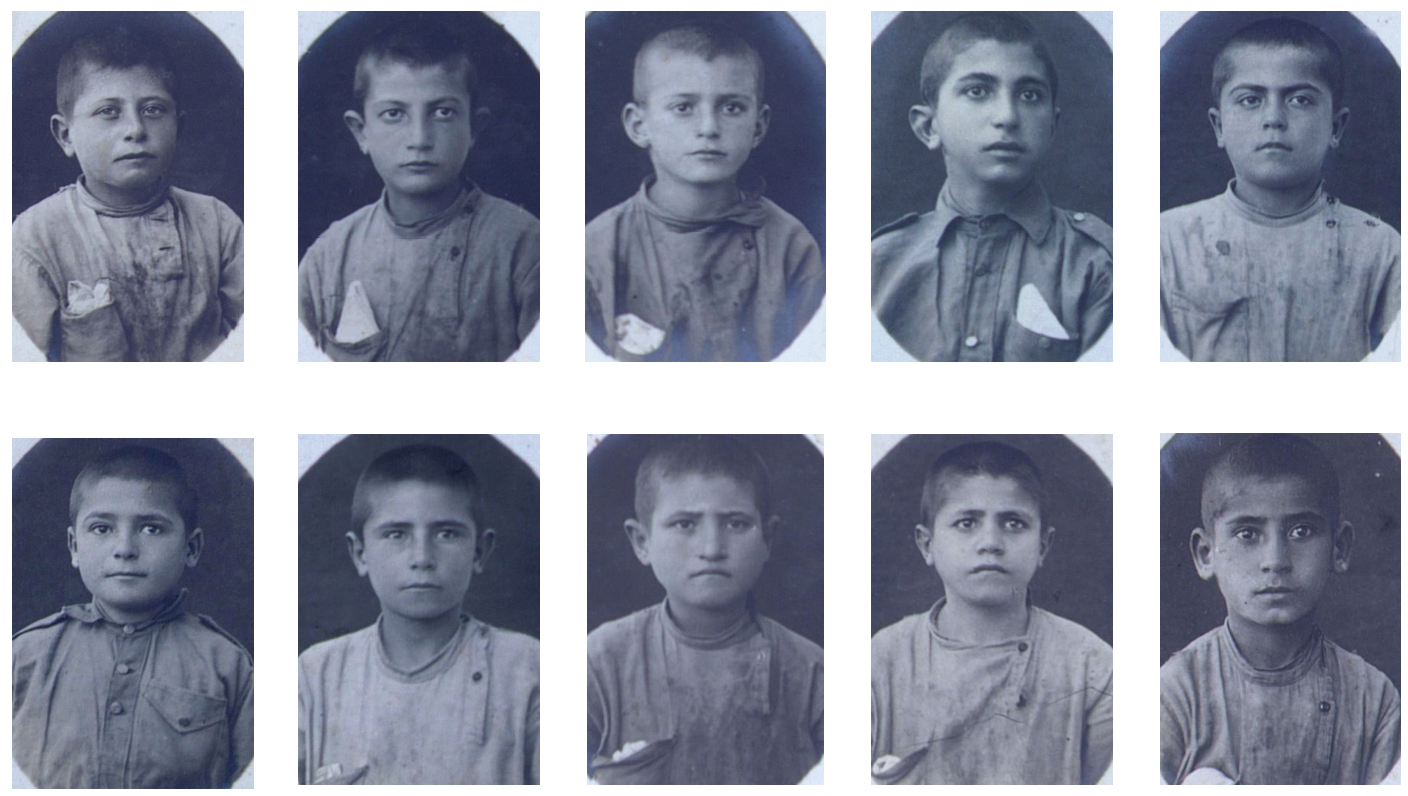
Armenian Genocide Survivors
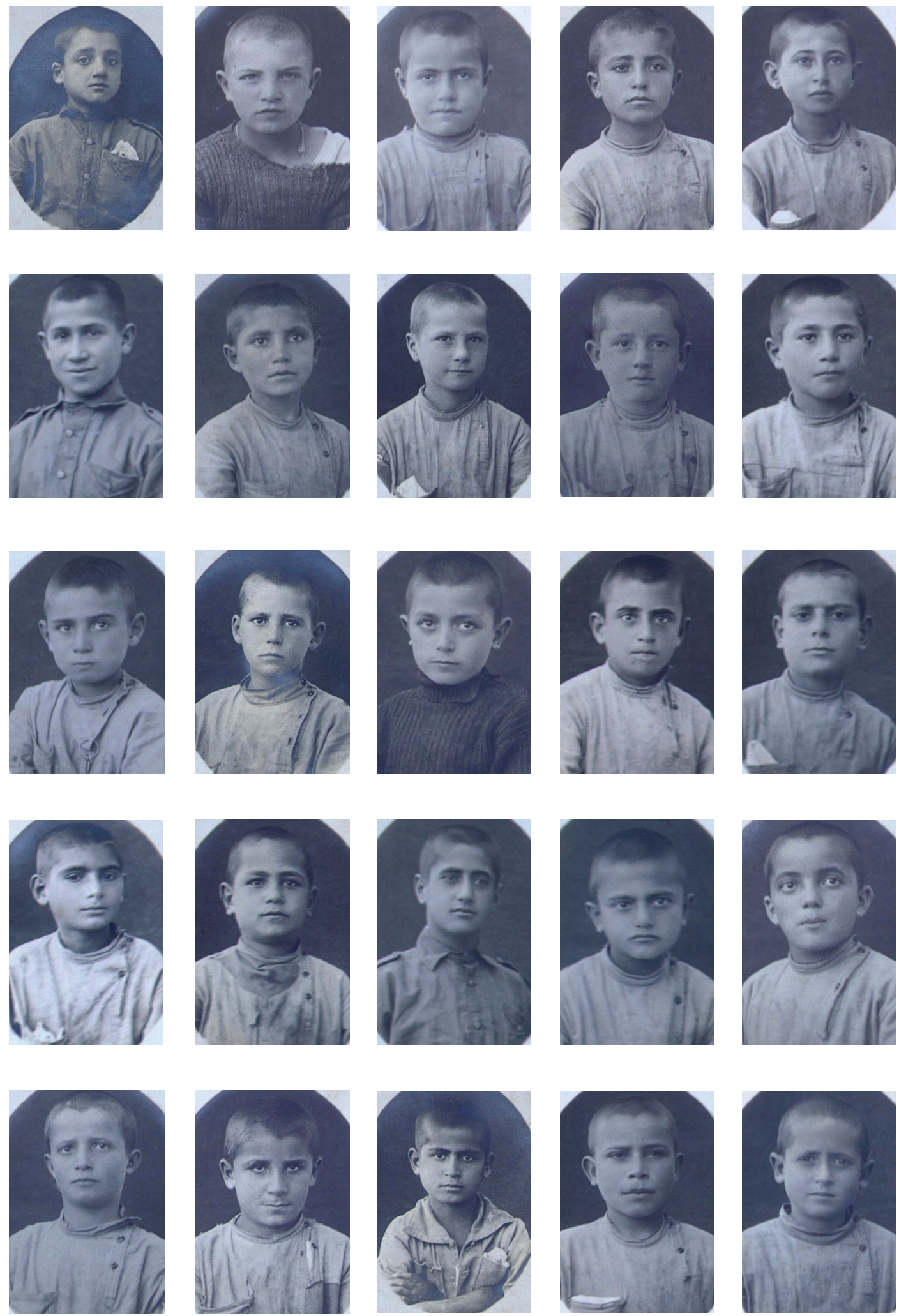
International Journal of Armenian Genocide Studies: Volume 5, No. 1, 2020
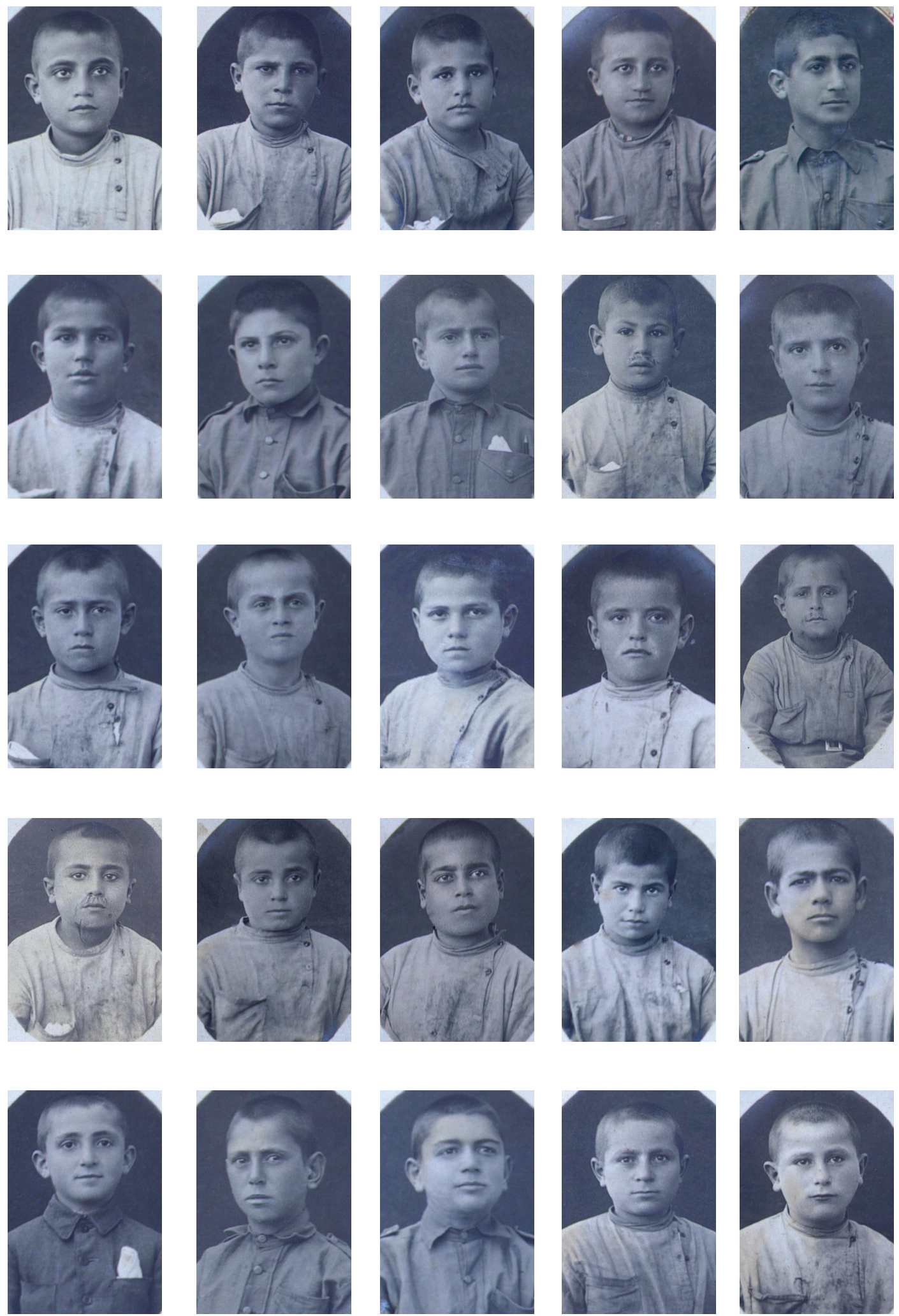
Armenian Genocide Survivors
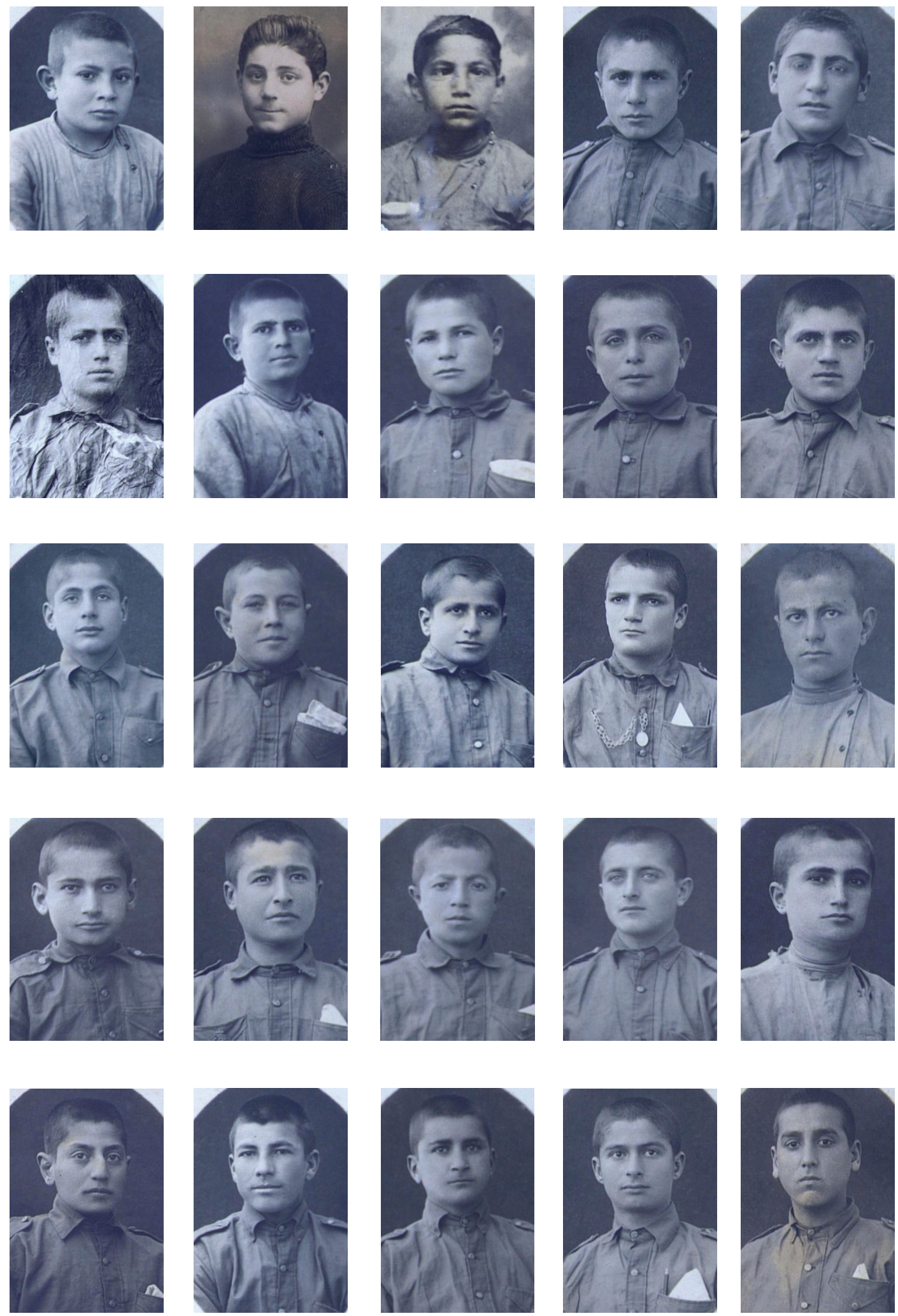
International Journal of Armenian Genocide Studies: Volume 5, No. 1, 2020
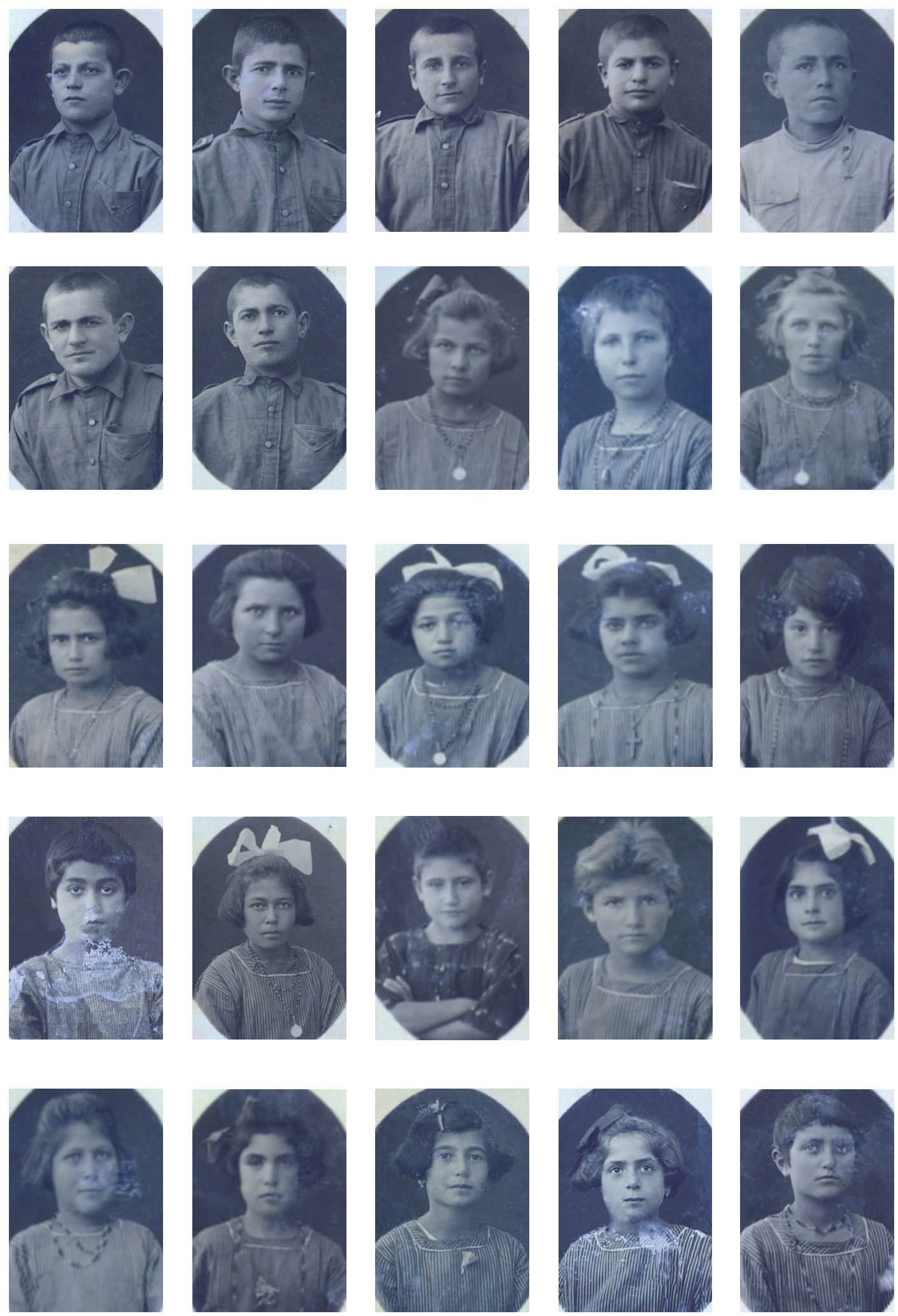
Armenian Genocide Survivors
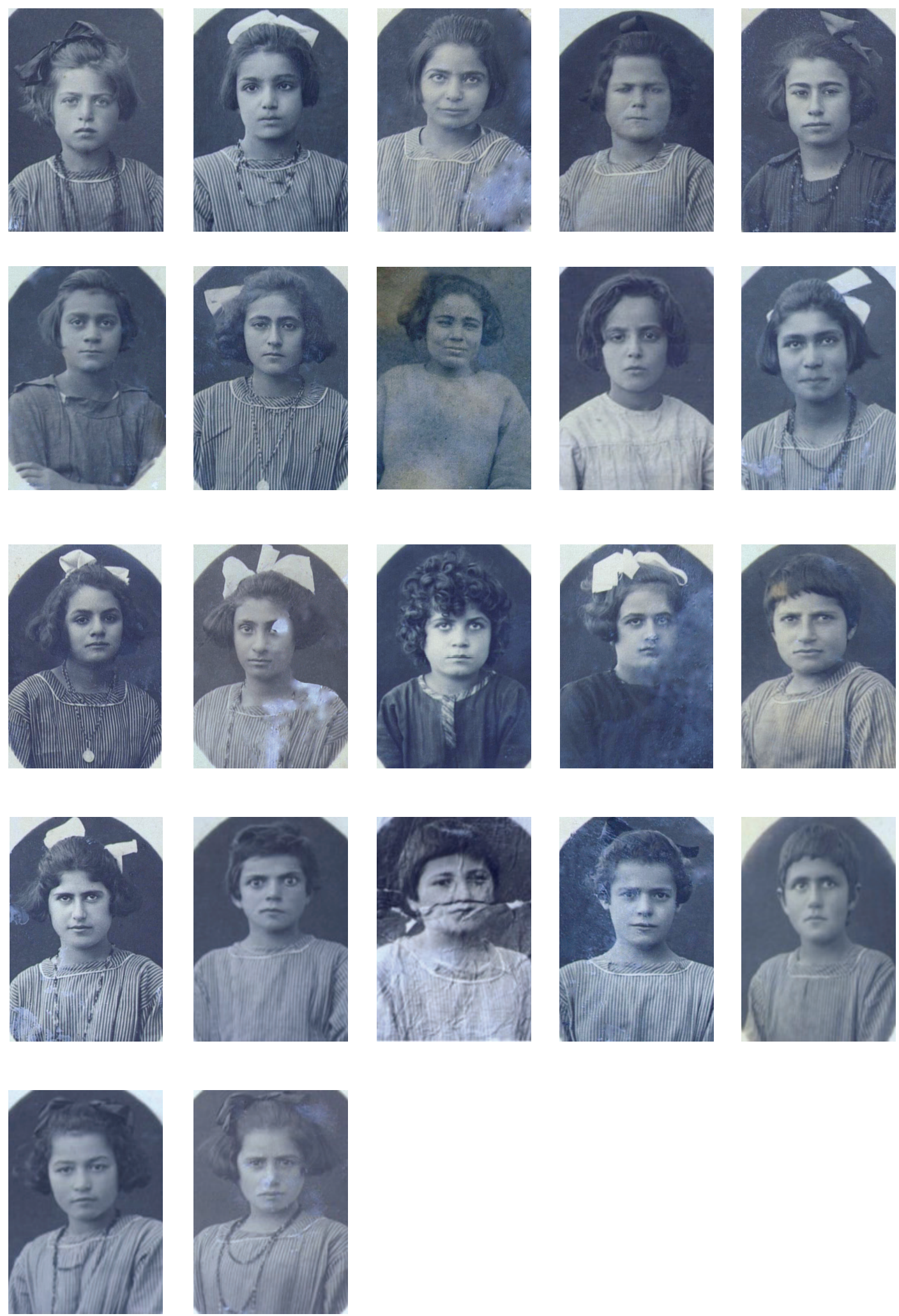